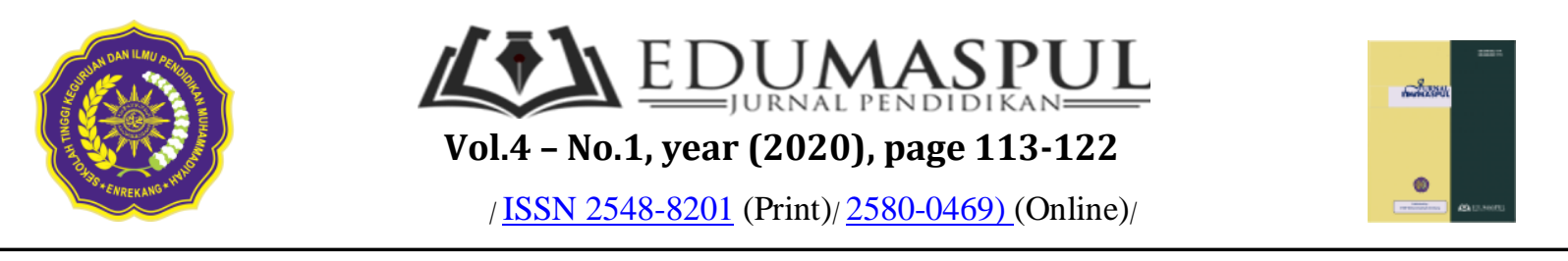

\title{
Model Pembelajaran Respons Verbal dalam Kemampuan Berbicara
}

\author{
Nurlaelah Nurlaelah ${ }^{1}$, Geminastiti Sakkir ${ }^{2 *}$ \\ ${ }^{1}$ (Pendidikan Bahasa Indonesia, FKIP, Universitas Muhammadiyah Sidenreng Rappang, Indonesia) \\ ${ }^{2}$ (Pendidikan Bahasa Inggris, FBS, Universitas Negeri Makassar, Indonesia) \\ * Corresponding Author. E-mail: ${ }^{2}$ hj.geminastitisakkir@yahoo.com
}

\begin{tabular}{|l|l|l|}
\hline Receive: $10 / 12 / 2019$ & Accepted: 02/02/2020 & Published: 02/03/2020
\end{tabular}

\begin{abstract}
Abstrak
Tujuan penelitian ini untuk melihat adakah pengaruh penerapan model pembelajaran respon verbal terhadap kemampuan berbicara Siswa Kelas X Madrasah Aliyah PP DDI AsSalman Allakuang Kabupaten Sidenreng Rappang. Penelitian ini dilaksanakan di Madrasah Aliyah PP DDI As-Salman Allakuang Kabupaten Sidenreng Rappang. Metode penelitian yang digunakan adalah metode kuantitatif. Subjek penelitiannya adalah siswa kelas $X$ Madrasah Aliyah PP DDI As-Salman Allakuang Kabupaten Sidenreng Rappang Tahun Pelajaran 2016/2017. Teknik pengumpulan data yang digunakan adalah tes dengan dua tahap pengambilan data, yaitu tes tahap pertama untuk mengetahui kemampuan berbicara siswa sebelum diberikan perlakuan (pretest) dan tes tahap kedua untuk mengetahui kemampuan berbicara siswa setelah diberikan perlakuan (posttest). Hasil berdasarkan pada db sebesar 52 yang dikonversi ke $t_{\text {tabel }}$ pada taraf signifikansi $5 \%$ diperoleh hasil sebesar 1,671 . Kriteria pengajuan adaah jika $t_{\text {hitung }} \geq t_{\text {tabel }}$ maka $H_{a}$ diterima dan $H_{o}$ ditolak, sebaliknya jika $t_{\text {hitung }} \leq$ ttabel maka $\mathrm{H}_{\mathrm{a}}$ ditolak dan $\mathrm{H}_{\mathrm{o}}$ diterima. Hasilnya thitung yang diperoleh besarnya 2,33 lebih besar dari $t_{\text {tabel, }}$ maka hipotesis alternatif diterima dan hipotesis nihil ditolak. Berdasarkan hasil tersebut disimpulkan bahwa penerapan model pembelajaran respons verbal secara signifikan memengaruhi kemampuan berbicara siswa kelas $X$ Madrasah Aliyah PP DDI AsSalman Allakuang Kabupaten Sidenreng Rappang.
\end{abstract}

Kata Kunci: Pengaruh, Model Pembelajaran, Respons Verbal, Berbicara

\section{Abstract (English-Indonesia)}

The purpose of this study is to find out the effect of the implementation of verbal response learning model to the speaking ability students of Class X Madrasah Aliyah PP DDI As-Salman Allakuang Sidenreng Rappang Regency. This research was conducted in Madrasah Aliyah PP DDI As-Salman Allakuang Sidenreng Rappang Regency. The research method used quantitative method. The subject of the research is the students of class $X$ Madrasah Aliyah PP DDI As-Salman Allakuang Sidenreng Rappang Regency academic year 2016/2017. The data collection technique used a test with two stages of data retrieval, the first test to determine the speaking ability before the students were given treatment (pretest) and the 
second stage to determine students' speaking ability after being given treatment (posttest). Results based on $d b$ of 52 converted to $t$-table at the $5 \%$ significance level obtained the price of 1.671. Criteria of submission are if $t$-test $\geq t$-tabel then Ha accepted and Ho rejected, otherwise if $t$-test $\leq t$-table then $\mathrm{Ha}$ rejected and Ho accepted. It turns out that $t$-test is magnitude 2.33 more than $t$-table, hence alternative hypothesis accepted and null hypothesis rejected. Based on these results it can be concluded that the application of verbal response learning model significantly affects the speaking ability of grade X Madrasah Aliyah PP DDI As-Salman Allakuang of Sidenreng Rappang Regency.

Keywords: Effect, Learning Model, Verbal Response, Speaking

\section{Pendahuluan}

Bahasa merupakan alat komunikasi sekaligus menjadi alat berpikir bagi manusia, baik secara lisan maupun tertulis, bersifat dinamis, selalu berubah. Perkembangan masyarakat bahasa dapat menjadi penyebab terjadinya perubahan bahasa. Hal ini menandakan bahwa bahasa merupakan hasil kebudayaan manusia yang mengalami perkembangan sesuai dengan tingkat kemajuan masyarakatnya. Perkembangan bahasa dapat terjadi pada bidang bentuk dan makna kata, leksikal atau gramatikal.

Kurikulum 2013 di tingkat Sekolah Menengah Atas atau yang sederajat mengarahkan pembelajaran bahasa Indonesia untuk meningkatkan kemampuan siswa dalam berkomunikasi dengan menggunakan bahasa Indonesia yang baik dan benar, baik secara lisan maupun tulisan, serta menumbuhkan apresiasi terhadap hasil karya kesusastraan Bangsa Indonesia.

Untuk mampu berkomunikasi dengan baik, manusia dituntut untuk memiliki keterampilan dalam berbahasa. Terdapat 4 keterampilan berbahasa dalam pembelajaran bahasa Indonesia, yaitu keterampilan menyimak, kemampuan berbicara, keterampilan membaca, dan keterampilan menulis. Pada dasarnya, keempat keterampilan ini memiliki hubungan yang erat dan saling berkaitan satu sama lain.

Kemampuan berbicara merupakan salah satu pengajaran bahasa Indonesia yang mengharapkan siswa mampu atau terampil dalam berbicara sehingga siswa memiliki kemampuan berkomunikasi secara efektif dan efisien serta etika yang sesuai dengan nilai-nilai religius dan tidak bertentangan dengan falsafah hidup Bangsa Indonesia, yaitu Pancasila. Penggunaan bahasa Indonesia dalam kemampuan berbicara untuk meningkatkan kemampuan intelektual, serta kematangan emosional dan sosial.

Dalam pembelajaran bahasa Indonesia, kemampuan berbicara harus mendapatkan perhatian lebih agar siswa mampu berkomunikasi dengan baik dan benar. Hal ini dikarenakan siswa merupakan anggota masyarakat yang dituntut untuk terampil berbahasa agar mampu untuk mengekspresikan dirinya.

Tetapi, pada kenyataannya tidak sedikit siswa yang belum terampil dalam berbahasa, khususnya berbicara. Permasalahan pertama adalah kepercayaan diri siswa yang masih rendah. Ketika guru menyampaikan pertanyaan, hanya sebagian kecil siswa yang menjawab. Bahkan hanya diam saja ketika guru bertanya mengenai pelajaran atau materi yang belum dikuasai. Demikian pula ketika 
siswa diharapkan untuk berbicara di depan kelas, mereka masih belum berani.

Permasalahan yang kedua adalah kemampuan berbicara siswa dari segi kebahasaan dan nonkebahasaan. Dari segi kebahasaan, masih banyak siswa yang ketika berbicara tidak memperhatikan ketepatan gaya bahasa, struktur kata, intonasi, dan pilihan kata. Sebagian besar siswa masih menggunakan bahasa ibu yang menandakan bahwa perbendaharaan kata yang dimiliki siswa masih kurang. Hal ini yang membuat siswa ragu untuk berbicara, kurang lancar atau terbata-bata saat berbicara, bahkan mengucapkan kata secara berulang-ulang karena keterbatasan kosakata tersebut. Hal ini yang menyebabkan pendengar kurang memahami yang disampaikan oleh pembicara. Dari segi nonkebahasaan, masih banyak siswa yang ketika berbicara gerak dan mimiknya kurang tepat, pandangan matanya masih tidak terarah, sikapnya masih kaku, suaranya tidak lantang cenderung seperti orang yang sedang berbisik, dan belum menguasai topik yang sedang dibicarakan.

Permasalahan yang ketiga adalah guru masih mendominasi proses pembelajaran dengan metode ceramahnya. Siswa terbiasa dengan pembelajaran yang bersifat penjelasan yang diakhiri dengan menyelesaikan tugas. Guru kurang mengaktifkan siswa sehingga tidak terlatih untuk terampil berbicara. Tentunya hal ini menyebabkan siswa kurang termotivasi untuk terampil berbicara. Metode-metode pengajaran yang diterapkan oleh guru belum bervariatif, hanya sekadar Tanya jawab, berdialog, dan bercerita. Proses pembelajaran akan lebih mudah jika siswa terlibat aktif dalam pembelajaran, termasuk berbicara untuk menyalurkan ide, pikiran, gagasan, dan atau sarannya.

Untuk memecahkan suatu permasalahan pada kemampuan berbicara siswa, guru harus lebih kreatif dalam memilih metode pengajaran yang akan sangat memengaruhi keberhasilan pencapaian tujuan dalam kegiatan proses pembelajaran. Guru yang kreatif akan menciptakan suasana belajar yang sesuai harapan siswa sehingga siswa tidak akan merasa jenuh dalam menerima pembelajaran dan dapat membuat siswa menjadi lebih aktif.

Ada beberapa penelitian sebelumnya yang memfokuskan pada peningkatan kemampuan berbicara, yaitu Sukatmi (2009), dengan judul penelitian "Upaya Meningkatkan Kemampuan berbicara dengan Media Gambar". Penelitian tindakan kelas pada siswa kelas V SD Negeri II Nambangan, Selogiri, Wonogiri. Hasil penelitiannya menyatakan bahwa dengan menggunakan media gambar dapat meningkatkan kemampuan berbicara siswa. Khumairoh (2015), dengan judul penelitian "Pengaruh Penerapan Metode Debat terhadap Kemampuan berbicara Siswa Kelas V MI Misbahul Falah Duren Mekar Kota Depok". Hasil penelitian yang ditemukan adalah simpulan yang menyatakan bahwa penerapan metode debat berpengaruh terhadap kemampuan berbicara siswa.

Namun, fokus pada penelitian adalah penerapan suatu model pembelajaran untuk merangsang kemampuan berbicara siswa. Adapun judul penelitiannya yaitu "Pengaruh Penerapan Model Pembelajaran Respons Verbal terhadap Kemampuan Berbicara Siswa Kelas X MadrasahAliyah PP DDI As-Salman Allakuang Kabupaten Sidenreng Rappang".

Belajar adalah suatu proses usaha yang dilakukan individu untuk memperoleh perubahan tingkah laku yang baru secara keseluruhan sebagai hasil pengalaman individu itu sendiri dalam interaksinya dengan lingkungan" (Ibrahim dan Syaodih, 1996: 3). Seseorang yang sedang belajar berarti secara sadar sedang mengerahkan 
tenaga dan pikirannya untuk memperoleh ilmu, keahlian ataupun keterampilan melalui kegiatan mengamati, mencoba, dan mengikuti aturan. Belajar adalah proses perubahan perilaku secara aktif, proses mereaksi terhadap semua situasi yang ada di sekitar individu, proses yang diarahkan pada suatu tujuan, proses berbuatan melalui berbagai pengalaman, proses melihat, mengamati, dan memahami sesuatu yang dipelajari.

Proses pembelajaran dialami sepanjang hayat seorang manusia serta dapat berlaku di manapun dan kapanpun. Pembelajaran mempunyai pengertian yang mirip dengan pengajaran, walaupun mempunyai konotasi yang berbeda. Dalam konteks pendidikan, guru mengajar supaya peserta didik dapat belajar dan menguasai isi pelajaran hingga mencapai sesuatu objektif yang ditentukan (aspek kognitif), juga dapat mempengaruhi perubahan sikap (aspek afektif), serta keterampilan (aspek psikomotor) seseorang peserta didik. Pengajaran memberi kesan hanya sebagai pekerjaan satu pihak, yaitu pekerjaan guru saja. Sedangkan pembelajaran juga menyiratkan adanya interaksi antara guru dengan peserta didik.

Instruction atau pembelajaran adalah suatu sistem yang bertujuan untuk membantu proses belajar siswa, yang berisi serangkaian peristiwa yang dirancang, disusun sedemikian rupa untuk mempengaruhi dan mendukung terjadinya proses belajar siswa yang bersifat internal (Gagne dan Briggs, 1979: 3; Sakkir, 2018).

Disimpulkan bahwa pembelajaran adalah usaha sadar dari guru untuk membuat siswa belajar, yaitu terjadinya perubahan tingkah laku pada diri siswa yang belajar, dimana perubahan itu dengan didapatkannya kemampuan baru yang berlaku dalam waktu yang relative lama dan karena adanya usaha.

Teori yang mendasari penelitian ini, berkenaan dengan konsep model, model pembelajaran, dan pembelajaran peningkatan kemampuan berbicara bahasa Indonesia. Model pembelajaran merupakan pedoman bagi guru dan murid dalam pelaksanaan proses belajar mengajar. Sebelum membicarakan halihwal model respons verbal melalui gambar dalam pembelajaran peningkatan kemampuan berbicara, terlebih dahulu akan dipaparkan mengenai pengertian model dalam kaitannya dengan pembelajaran.

Pribadi (2009: 86) mengatakan model adalah sesuatu yang menggambarkan pola berpikir. Sebuah model biasannya menggambarkan keseluruhan konsep yang saling berkaitan dan juga dapat dipandang sebagai upaya untuk mengkonkretkan sebuah teori sekaligus juga merupakan sebuah analogi dan representasi dari variabel-variabel yang terdapat di dalam teori tersebut.

Model merupakan suatu pola (contoh, acuan, ragam) dari sesuatu yang akan dibuat atau dihasilkan (Depdiknas, 2005: 751). Model pembelajaran adalah suatu perencanaan atau suatu pola yang digunakan sebagai pedoman dalam merencanakan pembelajaran di kelas atau pembelajaran dalam tutorial. Model pembelajaran mengacu pada pendekatan pembelajaran yang akan digunakan, termasuk di dalamnya tujuan-tujuan pengajaran, tahap-tahap dalam kegiatan pembelajaran, lingkungan pembelajaran, dan pengelolaan kelas.

Selanjutnya Joyce dan Weil (dalam Trianto, 2010: 51) menyatakan bahwa model mengajar merupakan model belajar dan dengan model tersebut guru dapat membantu siswa untuk mendapatkan atau memperoleh informasi, ide, keterampilan, cara berpikir dan mengekspresikan ide diri sendiri. Selain itu, juga mengajarkan bagaimana mereka belajar secara intruksional termasuk melalui buku, film, tape, dan program media komputer'. 
Kemp (1977) mengartikan model pembelajaran merupakan suatu perencanaan pembelajaran (desain instrucsional) yang digunakan dalam menentukan maksud dan tujuan setiap topik/ pokok bahasan (goals topics, and purposes), menganalisis karakteristik warga belajar (learnes characteristics), menyusun tujuan instruksional khusus (learning objectives), memilih isi pembelajaran (subject content), melakukan prates (pre assesment), melaksanakan kegiatan belajar mengajar/ sumber pembelajaran (teaching learning/ resources), mengadakan dukungan pelayanan (suport services), melaksanakan evaluasi (evaluation), dan membuat revisi (revise).

Dari pernyataan Joyce \& Weil maupun Kemp sependapat bahwa model pembelajaran merupakan suatu pola perencanaan pembelajaran yang digunakan dalam proses belajar mengajar. Dua pendapat di atas sejalan dengan pengertian model pembelajaran ini, yakni model pembelajaran adalah perencanaan yangdijadikan pedoman dalam pelaksanaan pembelajaran peningkatan kemampuan berbicara. Dapat dikatakan pula bahwa pengertian model yang dihubungkan dengan mengajar adalah kerangka konseptual yang melukiskan prosedur sistematis dalam mengorganisasikan pengalaman belajar untuk mencapai tujuan belajar tertentu dan berfungsi sebagai pedoman bagi para perancang pembelajaran. Oleh sebab itu, aktivitas pembelajaran benar-benar merupakan kegiatan yang mempunyai tujuan dan tertata secara sistematis pada pola, acuan, atau ragam, yang dipergunakan untuk merencanakan ihwal pembelajaran.

Pendekatan dalam mengajar umumnya menempuh dua macam cara, yaitu memberikan stimulasi dan mengadakan pengarahan aktivitas belajar. Pembelajaran dengan model respons verbal dipandang sebagai suatu pendekatan alternatif terhadap pengajaran dipraktis di dalam kelas yang banyak memberikan kesempatan kepada siswa untuk mempelajari masalah sosial dan personal yang berarti melalui keterlibatan langsung dan partisipasi pribadi. Model ini menuntut para siswa terfokus pada topik yang telah ditentukan sebelumnya dan mengajukan pendapat yang berkaitan dengan topik tersebut.

Menurut B. F. Skinner (dalam Sagala, 2010: 14) pendekatan berdasarkan respons verbal berpusat pada siswa, memfokuskan pada pemerolehan pengetahuan dengan respons terhadap teks atau melalui bentuk gambar. Seluruh tujuannya untuk memotivasi siswa dalam membaca dengan menghubungkan tema dan topik yang digambarkan melalui peningkatan kemampuan berbicara bahasa Indonesia.

Selain memeriksa bagaimana pembaca menggunakan sikapnya, peneliti juga tertarik pada bagaimana tindakan merespons sebagai proses budaya, berfungsi membentuk, menegaskan kembali, menjelaskan atau menantang sikap. Melalui merespons dapat mendefinisikan sikap, keyakinan kita dan pada akhirnya berkembang terhadap diri kita sendiri. Seperti yang dinyatakan oleh Robert M. Gagne (dalam Pribadi, 2009: 98), respons adalah suatu tindakan atau peristiwa budaya terhadap situasi stimulus yang dihadirkan.

Adapun dalam Kamus Besar Bahasa Indonesia (Depdiknas 2005: 952) respons adalah tanggapan, reaksi, atau jawaban. Dalam belajar dengan respons verbal, para siswa berpartisipasi secara aktif membentuk beberapa kelompok kecil yang masing- masing terdiri atas empat orang siswa. Tiap-tiap kelompok berdiskusi dengan topik yang berbeda antara kelompok satu dengan yang lainya, kemudian hasil diskusi kelompok tersebut dipresentasikan di depan kelas sedangkan 
teman yang lain siap dengan berbagai pertanyaan sesuai dengan objek pembelajaran. Kegiatan atau aktivitas pembelajaran didesain dengan tujuan untuk memfasilitasi siswa mencapai kompetensi atau tujuan pembelajaran.

Berbicara adalah kemampuan mengucapkan bunyi artikulasi atau katakata untuk mengekspresikan, menyatakan atau menyampaikan pikiran, gagasan, dan perasaan. Tarigan (2008:16) mengungkapkan bahwa berbicara merupakan suatu sistem tanda-tanda yang dapat didengar (audible) dan yang kelihatan (visible) yang memanfaatkan sejumlah otot dan jaringan otot tubuh manusia demimaksud dan tujuan-tujuan gagasan atau ide-ide yang dikombinasikan. Selanjutnya, dikatakan bahwa berbicara merupakan suatu bentuk perilakumanusia yang memanfaatkan faktor-faktor fisik, psikologis, neurologis, semantik, dan linguistik sedemikian ekstensif, secara luas sehingga dapat dianggap sebagai alat manusia yang paling penting bagi kontrolsosial.

Sejalan dengan pendapat di atas, Tarigan (1990: 149) menyatakan bahwa berbicara adalah keterampilan menyampaikan pesan melalui bahasa lisan. Kaitan antara pesan dan bahasa lisan sebagai media penyampaian sangat berat. Pesan yang diterima oleh pendengar tidaklah dalam wujud asli, tetapi dalam bentuk lain yakni bunyi bahasa. Pendengar kemudian mencoba mengalihkan pesan dalam bentuk bunyi bahasa itu menjadi bentuksemula.

Dengan demikian, berbicara lebih dari sekadar pengucapan bunyi-bunyi atau kata-kata. Berbicara adalah suatu alat untuk mengkomunikasikan gagasangagasan yang disusun serta dikembangkan sesuai dengan kebutuhan-kebutuhan sang pendengar atau penyimak. Mujlgrave (dalam Tarigan, 2008: 16) mengungkapkan bahwa berbicara merupakan instrumen yang mengungkapkan kepada penyimak hampir-hampir secara langsung apakah sang pembicara memahami atau tidak, pada saat dia mengkomunikasikan gagasan-gagasannya; apakah dia waspada serta antusias atau tidak.

Batasan berbicara yang hampir sama dengan Tarigan dikemukakan oleh Arsjad (1988:17-19) bahwa kemampuan berbicara adalah kemampuan mengucapkan bunyibunyi artikulasi atau mengucapkan katakata untuk mengekspresikan, menyatakan, menyampaikan pikiran, gagasan, dan perasaan.Pendengar menerima informasi melalui rangkaian nada, tekanan, dan penempatan persendian (juncture). Jika komunikasi berlangsung secara tatap muka, ditambah lagi dengan gerak tangan dan raut muka (mimik) pembicara.

Tujuan utama dari berbicara adalah untuk berkomunikasi. Agar dapat menyampaikan informasi dengan efektif, sebaiknya pembicara betul-betul memahami isi pembicaraannya, di samping juga harus dapat mengevaluasi efek komunikasinya terhadap pendengar. Jadi, bukan hanya apa yang akan dibicarakan, tetapi bagaimana mengemukakannya.

$\mathrm{Hal}$ ini menyangkut masalah bahasa dan pengucapan bunyi-bunyi bahasa tersebut. Yang dimaksud ucapan adalah seluruh kegiatan yang kita lakukan dalam memproduksi bunyi bahasa, yang meliputi artikulasi, yaitu bagaimana posisi alat bicara, seperti lidah, gigi, bibir, dan langitlangit pada waktu kita membentuk bunyi, baik vokal maupun konsonan.

Untuk dapat menjadi pembicara yang baik, seorang pembicara selain harus memberikan kesan bahwa ia menguasai masalah yang dibicarakan, si pembicara juga harus memperlihatkan keberanian dan kegairahan. Selain itu pembicara harus berbicara dengan jelas dan tepat. Dalam hal ini ada beberapa faktor yang harus diperhatikan oleh si pembicara untuk keefektifan berbicara, yaitu faktor 
kebahasaan dan faktor nonkebahasaan. Tidak dapat disangkal lagi bahwa tujuan utama berbicara adalah berkomunikasi.

Ochs dan Winker (dalam Tarigan, 2008: 17) menyederhanakan berbicara menjadi tiga tujuan umum yaitu: (1) memberitahukan, melaporkan (to inform); (2) menjamu, menghibur (to entertain) dan; (3) membujuk, mengajak, mendesak, meyakinkan (to persuade). Gabungan atau campuran dari maksud-maksud tersebut mungkin saja terjadi, begitupun dengan menghibur dan meyakinkan sekaligus. Larry King mengatakan bahwa kesuksesan

seseorang baik dibidang sosial maupun profesional, dapat dilalui dengan kegiatan kecakapan berbicara begitu sebaliknya apabila seseorang kurang meyakinkan dalam berbicara maka kesuksesan akan sulit tercapai. Di samping itu berbicara merupakan bentuk komunikasi manusia yang paling mendasar, yang membedakan kita sebagai spesies. Sesuai dengan sifat dari pembelajaran seperti dibawah ini.

Berkaitan dengan hal ini, Keraf (1994: 321) mengatakan bahwa bila pembicaraan berusaha untuk mempengaruhi keyakinan atau sikap mental atau intelektual pendengar, maka pembicaraan ini bertujuan untuk meyakinkan. Pada umumnya berbicara yang disampaikan dewasa ini mengandung tujuan ini. Alat yang esensial dari komposisi lisan semacam ini adalah argumentasi. Karena itu komposisi semacam ini disertai bukti-bukti dan fakta-fakta yang kongkret.

\section{Metode}

Desain yang digunakan dalam penelitian ini adalah quasi eksperimental design yang mengambil bentuk penilaian pre-test post-test control group design. Penerapan model respons verbal bertujuan untuk mengetahui dan membandingkan data hasil nilai sebelum dan sesudah perlakuan pada subjek yang sama. Pada desain ini, observasi dilakukan sebelum ekperimen dan sesudah eksperimen. Observasi yang dilakukan sebelum eksperimen $\left(\mathrm{O}_{1}\right)$ disebut pre-test dan obeservasi yang dilakukan sesudah eksperimen $\left(\mathrm{O}_{2}\right)$ disebut post-test.

Penelitian ini dilaksanakan pada dua kelas, yaitu dipilih secara random berupa kelas eksperimen $(\mathrm{x}$ ) yang diberi perlakuan dan kelas kontrol (y) yang tidak diberi perlakuan. Kelas eksperimen dengan menerapkan model respons verbal melalui gambar, sedangkan kelas kontrol dengan menerapkan model konvensional, metode ceramah, dan penugasan. Kedua kelas diberi tes awal dan tes akhir yang sama untuk mengetahui efektivitas perlakuan, skor tes awal, dan tes akhir.

\section{Hasil dan Pembahasan}

Penelitian ini dilakukan pada siswa kelas X Madrasah Aliyah PP DDI As-Salman Allakuang Kabupaten Sidenreng Rappang dengan menggunakan teknik tes, observasi, wawancara dan angket dalam mengumpulkan data dan mengolahnya dengan t-tes. Berikut deskripsi secara rinci pada tiap variabelnya.

Hasil analisis kemampuan berbicara sebelum perlakuan. Berikut disajikan data perolehan nilai dari tes kemampuan berbicara sebelum perlakuan (pre-test).

Tabel 1. Hasil Pre-test Kelas Eksperimen dan Kelas Kontrol 
Jurnal Edumaspul, 4 (1), Year 2020 - 120

(Nurlaelah \& Geminastiti Sakkir)

\begin{tabular}{|cccc|cccc|}
\hline \multicolumn{3}{|c|}{ Kelas Eksperimen $(\mathbf{x})$} & \multicolumn{4}{c|}{ Kelas Kontrol (y) } \\
\hline No & Kode & $\begin{array}{c}\text { Nilai } \\
(\mathbf{x})\end{array}$ & $\mathbf{X}^{2}$ & No & Kode & $\begin{array}{c}\text { Nilai } \\
(\mathbf{y})\end{array}$ & Y $^{2}$ \\
\hline 1 & L 1 & 78 & 6084 & 1 & L 9 & 76 & 5776 \\
\hline 2 & L 2 & 71 & 5041 & 2 & L 10 & 73 & 5329 \\
\hline 3 & L 3 & 80 & 6400 & 3 & L 11 & 75 & 5625 \\
\hline 4 & L 4 & 80 & 6400 & 4 & L 12 & 82 & 6724 \\
\hline 5 & L 5 & 73 & 5329 & 5 & L 13 & 66 & 4356 \\
\hline 6 & L 6 & 82 & 6724 & 6 & L 14 & 72 & 5184 \\
\hline 7 & L 7 & 71 & 5041 & 7 & L 15 & 76 & 5776 \\
\hline 8 & L 8 & 72 & 5184 & 8 & L 16 & 78 & 6084 \\
\hline 9 & P 1 & 73 & 5329 & 9 & P 20 & 75 & 5625 \\
\hline 10 & P 2 & 75 & 5625 & 10 & P 21 & 66 & 4356 \\
\hline 11 & P 3 & 82 & 6724 & 11 & P 22 & 80 & 6400 \\
\hline 12 & P 4 & 66 & 4356 & 12 & P 23 & 80 & 6400 \\
\hline 13 & P 5 & 71 & 5041 & 13 & P 24 & 76 & 5776 \\
\hline 14 & P 6 & 73 & 5329 & 14 & P 25 & 78 & 6084 \\
\hline 15 & P 7 & 78 & 6084 & 15 & P 26 & 72 & 5184 \\
\hline 16 & P 8 & 66 & 4356 & 16 & P 27 & 80 & 6400 \\
\hline 17 & P 9 & 71 & 5041 & 17 & P 28 & 80 & 6400 \\
\hline 18 & P 10 & 80 & 6400 & 18 & P 29 & 76 & 5776 \\
\hline 19 & P 11 & 73 & 5329 & 19 & P 30 & 75 & 5625 \\
\hline 20 & P 12 & 78 & 6084 & 20 & P 31 & 82 & 6724 \\
\hline 21 & P 13 & 82 & 6724 & 21 & P 32 & 72 & 5184 \\
\hline 22 & P 14 & 66 & 4356 & 22 & P 33 & 80 & 6400 \\
\hline 23 & P 15 & 78 & 6084 & 23 & P 34 & 76 & 5776 \\
\hline 24 & P 16 & 72 & 5184 & 24 & P 35 & 75 & 5625 \\
\hline 25 & P 17 & 76 & 5776 & 25 & P 36 & 71 & 5041 \\
\hline 26 & P 18 & 73 & 5329 & 26 & P 37 & 72 & 5184 \\
\hline 27 & P 19 & 78 & 6084 & 27 & P 38 & 80 & 6400 \\
\hline & x & 2018 & 151438 & & & 2044 & 155214 \\
\hline & & & & & & \\
\hline
\end{tabular}

Data pada tabel 1. selanjutnya akan dianalisis nilai rata-rata masing-masing kelas dengan menggunakan rumus mean. Berikut penyelesaiannya.

Mean kelompok eksperimen $(X)$ dan kelompok kontrol $(\mathrm{Y})$ adalah:

$$
\begin{aligned}
& M_{x}=\frac{\sum X}{N}=\frac{2018}{27}=74,74 \\
& M_{y}=\frac{\sum Y}{N}=\frac{2044}{27}=75,70
\end{aligned}
$$

Berdasarkan rumus mean yang digunakan diperoleh nilai rata-rata untuk kelas eksperimen sebesar $74,74 \%$ dan untuk kelas kontrol diperoleh nilai rata-rata sebesar $75,70 \%$. Nilai rata-rata kelas eksperimen kurang dari nilai rata-rata kelas kontrol $(\mathrm{x}<\mathrm{y})$. Jadi dapat disimpulkan bahwa kemampuan berbicara siswa pada kelompok eksperimen lebih rendah jika dibandingkan dengan kelas kontrol pada uji kemampuan berbicara sebelum diberikan

Hasil analisis kemampuan berbicara sesudah perlakuan. Berikut disajikan data perolehan nilai dari tes kemampuan berbicara sesudah diberikan perlakuan (post-test).

Tabel 2. Hasil Post-test Kelas

\begin{tabular}{|c|c|c|c|c|c|c|c|}
\hline \multicolumn{4}{|c|}{ Kelas Eksperimen (x) } & \multicolumn{4}{|c|}{ Kelas Kontrol (y) } \\
\hline No & Kode & $\begin{array}{c}\text { Nilai } \\
(\mathbf{x})\end{array}$ & $\mathbf{X}^{2}$ & No & Kode & $\begin{array}{c}\text { Nilai } \\
\text { (y) }\end{array}$ & $\mathbf{Y}^{2}$ \\
\hline 1 & L 1 & 80 & 6400 & 1 & L 9 & 78 & 6084 \\
\hline 2 & L 2 & 82 & 6724 & 2 & $\mathrm{~L} 10$ & 77 & 5929 \\
\hline 3 & L 3 & 81 & 6561 & 3 & $\mathrm{~L} 11$ & 75 & 5625 \\
\hline 4 & L 4 & 82 & 6724 & 4 & L 12 & 80 & 6400 \\
\hline 5 & L 5 & 79 & 6241 & 5 & L 13 & 77 & 5929 \\
\hline 6 & L 6 & 83 & 6889 & 6 & L 14 & 76 & 5776 \\
\hline 7 & L 7 & 78 & 6084 & 7 & $\mathrm{~L} 15$ & 79 & 6241 \\
\hline 8 & L 8 & 78 & 6084 & 8 & L 16 & 80 & 6400 \\
\hline 9 & P 1 & 80 & 6400 & 9 & P 20 & 80 & 6400 \\
\hline 10 & P 2 & 80 & 6400 & 10 & P 21 & 70 & 4900 \\
\hline 11 & P 3 & 82 & 6724 & 11 & P 22 & 80 & 6400 \\
\hline 12 & P 4 & 76 & 5776 & 12 & P 23 & 80 & 6400 \\
\hline 13 & P 5 & 78 & 6084 & 13 & P 24 & 78 & 6084 \\
\hline 14 & P 6 & 77 & 5929 & 14 & P 25 & 79 & 6241 \\
\hline 15 & P 7 & 80 & 6400 & 15 & P 26 & 77 & 5929 \\
\hline 16 & P 8 & 80 & 6400 & 16 & P 27 & 83 & 6889 \\
\hline 17 & P 9 & 82 & 6724 & 17 & P 28 & 84 & 7056 \\
\hline 18 & P 10 & 83 & 6889 & 18 & P 29 & 77 & 5929 \\
\hline 19 & P 11 & 79 & 6241 & 19 & P 30 & 75 & 5625 \\
\hline 20 & P 12 & 80 & 6400 & 20 & P 31 & 82 & 6724 \\
\hline 21 & P 13 & 81 & 6561 & 21 & P 32 & 76 & 5776 \\
\hline 22 & P 14 & 80 & 6400 & 22 & P 33 & 80 & 6400 \\
\hline 23 & P 15 & 78 & 6084 & 23 & P 34 & 76 & 5776 \\
\hline 24 & P 16 & 77 & 5929 & 24 & P 35 & 75 & 5625 \\
\hline 25 & P 17 & 76 & 5776 & 25 & P 36 & 73 & 5329 \\
\hline 26 & P 18 & 80 & 6400 & 26 & P 37 & 79 & 6241 \\
\hline 27 & P 19 & 78 & 6084 & 27 & P 38 & 80 & 6400 \\
\hline & & 2.150 & 171.308 & & & 2.106 & 164.508 \\
\hline
\end{tabular}
Eksperimen dan Kelas Kontrol.

Data pada tabel 4.2 selanjutnya akan dianalisis nilai rata-rata masing-masing kelas dengan menggunakan rumus mean. Berikut penyelesaiannya.

Mean kelompok eksperimen (X) dan kelompok kontrol $(\mathrm{Y})$ adalah:

$$
\begin{aligned}
& M_{x}=\frac{\sum X}{N}=\frac{2.150}{27}=79,63 \\
& M_{y}=\frac{\sum Y}{N}=\frac{2.106}{27}=78,00
\end{aligned}
$$
perlakuan. 
Berdasarkan rumus mean yang digunakan diperoleh nilai rata-rata untuk kelas eksperimen sebesar $79,63 \%$ dan untuk kelas kontrol diperoleh nilai rata-rata sebesar $78,00 \%$. Nilai rata-rata kelas eksperimen lebih dari nilai rata-rata kelas kontrol $(x>y)$. Hal ini menunjukkan bahwa nilai rata-rata pada kelas eksperimen mengalami kenaikan yang signifikan.

Berdasar pada besarnya nilai t.test, maka untuk mengetahui pengaruh variable bebas terhadap variable terikat tersebut signifikan atau tidak, maka thitungakan dibandingkan dengan ttabel. Dengan db sebesar 52, maka jika dikonversi ke ttabel pada taraf signifikan 5\% diperoleh nilai sebesar 1,671. Kriteria pengajuannya adalah jika thitung $\geq$ ttabel maka hipotesis alternatif diterima dan hipotesis nihil ditolak, sebaliknya jika thitung $\leq$ ttabel maka hipotesis alternatif ditolak dan hipotesis nihil diterima.

\section{Simpulan}

Berdasarkan pengolahan dan hasil analisis data, nilai t.tes sama dengan 2,33 dengan derajat bebas sama dengan 52 dengan kata lain hipotesis alternatif diterima dan hipotesis nihil ditolak, sehingga diperoleh simpulan yaitu, penerapan model pembelajaran respons verbal memiliki pengaruh yang signifikan terhadap kemampuan berbicara siswa kelas X Madrasah Aliyah PP DDI As-Salman Allakuang Kabupaten Sidenreng Rappang.

\section{Daftar Pustaka}

[1] Arsjad, Maidar dan Mukti. (1988). Pembinaan Kemampuan Berbicara Bahasa Indonesia. Jakarta: Erlangga.

[2] Depdiknas. (2005). Kamus Besar Bahasa Indonesia. Jakarta: Balai Pustaka.

[3] Gagne dan Briggs. (1979). Pengertian Pembelajaran.

http://www.scribd.com/doc/50015294/
13/B-Pengertian-pembelajaran-

menurut-beberapa-ahli (diakses pada tanggal 1 Juli 2019).

[4] Ibrahim, R dan Syaodih S, Nana. (1996). Perencanaan Pengajaran. Jakarta: PT. Rineka Cipta.

[5] Kemp. J. E. (1977). Instructional Design: Plan for Unit and Course Development Belmont, California: Fearon-Pitman Publisher.

[6] Keraf, Gorys. (1994). Argumentasi dan Narasi. Jakarta: Gramedia.

[7] Khumairoh. (2015). Pengaruh Penerapan Metode Debat terhadap Kemampuan berbicara Siswa Kelas V MI Misbahul Falah Duren Mekar Kota Depok. Tesis.

[8] Pribadi, B. A. (2009). Model Desain Sistem Pembelajaran. Jakarta: Dian Rakyat.

[9] Sagala, S. (2010). Analisis Kesalahan Berbahasa Indonesia. Surakarta: Yuma Pustaka.

[10] Sakkir, G. (2018). Pengembangan Modul Pengajaran Menulis Berbasis Facebook (Doctoral dissertation, Pascasarjana).

[11] Sakkir, G. (2018). Writing: Beginner. Deepublish.

https://books.google.co.id/books?id=2FI VDwAAQBAJ\&printsec $=$ frontcover \&hl=i $\mathrm{d \# v= \text {onepage } \& \mathrm { q } \& \mathrm { f } = \mathrm { false }}$

[12] Sakkir, G., \& Abrar, A. E. Y. (2018, November). "Students' Perception of the Implementation Facebook Group in Learning Writing Skill." In PROCEEDINGS OF THE 65th TEFLIN INTERNATIONAL CONFERENCE, vol. 65, no. 02. 2018.

[13] Sakkir, G., \& Dollah, S. (2019). Measuring students'writing skills using Facebook group application in EFL context. International Journal of Humanities and Innovation (IJHI), 2(3), 
Jurnal Edumaspul, 4 (1), Year 2020 - 122

(Nurlaelah \& Geminastiti Sakkir)

69-72.

https://doi.org/10.33750/ijhi.v2i3.43

[14] Sakkir, G., Rahman, Q., \& Salija, K. (2016). Students' Perception on Social Media in Writing Class at STKIP Muhammadiyah Rappang, Indonesia. International Journal of English Linguistics, 6(3), 170-175. doi: 10.5539/ijel.v6n3p170. URL: http://dx.doi.org/10.5539/ijel.v6n3p170

[15] Sugiyono. (2006). Metode Penelitian Kuantitatif, Kualitatif dan R\&D. Bandung: Alfabeta.

[16] Sukatmi. (2009). Upaya Meningkatkan Kemampuan berbicara dengan Media Gambar. Penelitian tindakan kelas pada siswa kelas V SD Negeri II Nambangan, Selogiri, Wonogiri.

[17] Tarigan, Djago, dan H. G. Tarigan. (1990). Teknik Pengajaran Kemampuan Berbahasa. Bandung: Angkasa.

[18] Tarigan, Henry Guntur. (2008). Berbicara sebagai Suatu Keterampilan Berbahasa. Bandung: Angkasa.

[19] Trianto. (2010). Model Pembelajaran Terpadu. Jakarta: PT. Bumi Aksara.

\section{Profil Penulis}

Penulis pertama bernama Nurlaelah, S. $\boldsymbol{P} \boldsymbol{d}$., $\boldsymbol{M}$. $\boldsymbol{P} \boldsymbol{d}$ merupakan dosen Pendidikan Bahasa Indonesia di Universitas Muhammadiyah Sidenreng Rappang (UMS Rappang). Penulis lahir di Rappang 25 Desember 1984. Pendidikan sarjana ditempuh di STKIP Muhammadiyah Rappang lulus pada tahun 2009, pada jenjang magister penulis melanjutkan kuliah di Universitas Muhammadiyah Makassar dengan jurusan yang linear yaitu Pendidikan Bahasa dan Sastra Indonesia lulus tahun 2018.

Penulis kedua bernama $\boldsymbol{D r}$. $\boldsymbol{H j}$. Geminastiti Sakkir, S. Pd., M. Pd. Penulis lahir di Pinrang, 08 Juni 1987. Penulis menempuh pendidikan sarjana di Universitas Negeri Makassar Jurusan Pendidikan Bahasa Inggris selesai tahun 2009 dan langsung melanjutkan pendidikan magister di kampus yang sama dan jurusan yang sama selesai pada tahun 2011. Tahun 2013, Penulis melanjutkan pendidikan doktor di UNM dan jurusan yang sama selesai pada Januari 2018. 